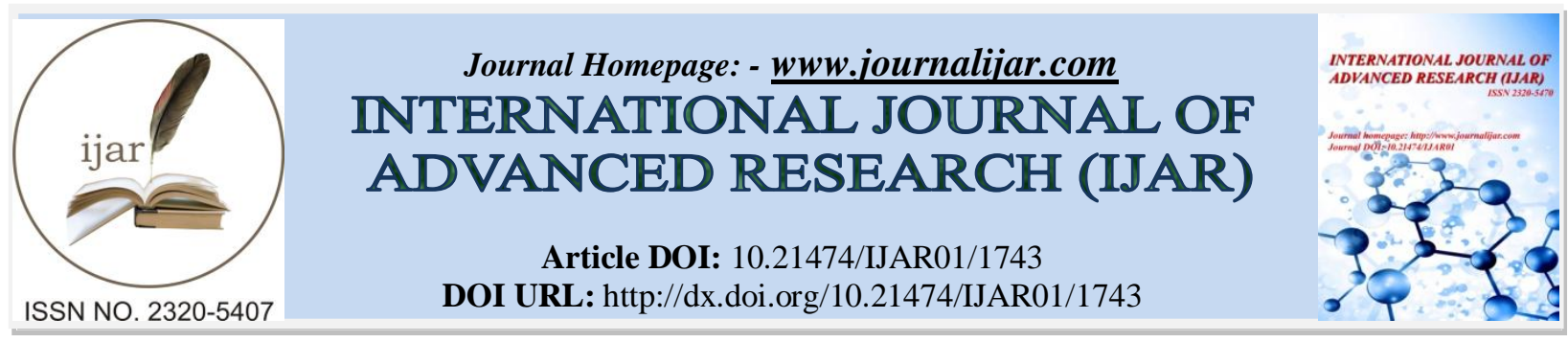

RESEARCH ARTICLE

\title{
MARKET ORIENTATION ADOPTION AND DEVELOPMENT OF THE STOCK MARKET IN DEVELOPING ECONOMIES.
}

Dr. Solomon A. Keelson.

Department of Marketing, School of Business, Takoradi Technical University, Box 256, Takoradi.

\section{Manuscript Info}

Manuscript History

Received: 12 July 2016

Final Accepted: 12 August 2016

Published: September 2016

Key words:-

Developing economies, economic development, market orientation, organisational performance, stock market,

\section{Abstract}

The purpose of this study is to determine how the market orientation adoption of listed firms can contribute to development of the stock market in developing economies. Using thirty senior officers selected from 36 Listed Companies in Ghana, a depth-interview approach is used to collect data from senior officers of the firms to investigate the current level of market orientation of listed firms in Ghana, and to assess the extent to which the levels of market orientation influence economic and non-economic performance of listed firms. The findings of the study revealed a relatively high level of market orientation of listed firms due to proper integration of management, organisational and external antecedents. Also, the level of market orientation of listed companies is strong enough to have significant influence on economic and non-economic performance of organisations. More importantly, the study acknowledged that the market oriented-culture of the listed firms could be used to develop and grow stock market in developing economies.

Copy Right, IJAR, 2016,. All rights reserved.

\section{Introduction:-}

Being market-oriented means a firm places the customer expectations at the center of products and services development (Grönroos, 2006). This implies that a market oriented firm, while considering customer needs prior to production, also involves the customer in the design and development of products and services in a manner that meets customer's needs and expectation to provide customers value. According to Chen and Quester (2009), the link between market orientation and customer value raises two important arguments: first, customer value is a theory emphasizing the implementation of customer-centric thinking in marketing and, second customer value is regarded as the foundation for achieving a positive organisational performance (Alhakimi \& Baharun, 2009). This suggests that Listed Companies need to do everything possible to provide value for their customers, and they would be rewarded with enhancement in their organisational performance.

The significance contribution of market orientation to organisational performance is acknowledged by the numerous studies that have been done in the field. In most of these studies, researchers have tried to conceptualize and measure market orientation with regards to organisational performance (Hafer \& Gresham, 2008; Alhakimi \& Baharun, 2010). Many of the studies in market orientation have supported the marketing requirement to continually satisfy customer needs and wants by the firm in order to improve organisational performance (Slater \& Narver 1994; Kotler \& Armstrong, 2010). 
Studies on market orientation and organisational performance have been conducted in several countries such as Bangladesh (Zebal, 2003), Mexico (Felix \& Hinck, 2005); Finland (Elg, 2008); Pakistan (Malik \& Naeem, 2009); China (Qu \& Ennew, 2009); Kosovo (Bytyqi, Zeqiri \& Hasani, 2010); and Malaysia (Mokhtar, Yusoff \& Arshad, 2010). Most of these studies supported market orientation's contribution to organisation performance. Thus, the level of market orientation of Listed Companies should be one of the critical determinants of both the economic and non-economic performance of these firms (Tomaskova, 2009), as well as business development in the market (Yartey, 2008).

Savitt (2001) examined the challenges of developing a market orientation in a transitional economy in the Czech Republic. He found that "shallow restructuring" (i.e., restructuring that does not contain significant programs and processes for operating in the economy) and the continuity of senior managers from the previous system were the main barriers to the development of market orientation. Zebal (2003) examined the model of market orientation for consumer goods manufacturing companies in Bangladesh. The study found that market orientation of consumer goods manufacturing companies in Bangladesh was determined by organisational, management and external antecedents. The study also identified a significant impact of market orientation on both the economic and noneconomic performance of business. Qu and Ennew (2009) investigated the development of market orientation in a Transitional Economy in China. Their study posited that the development of market orientation is significantly constrained by three factors (i.e., government regulation, ownership structure and resource availability). In another development, Alhkami \& Baharun (2010) developed an integrative model of market orientation constructs in consumer goods industry in Malaysia. The study found that marketing concept adoption was a significant antecedent of customer, competitor and profit orientation and inter-functional coordination. Earlier, Hafer \& Gresham (2008) had studied the relationships between organisational climate variables and the three components of market orientation in order to confirm the findings of Jaworski and Kohli (1993) in an industry-specific sample of crossfunctional new product development teams at the sub-SBU level. The study also identified organisational reward systems, organisational commitment and esprit de corps as antecedents of market orientation. These studies support the fact that the level of market orientation is attained only with the existence of certain key antecedents to drive the implementation of the marketing concept.

A cursory look at the existing literature shows the extensive work that has been done to study market orientation, especially, its relationship with organisational performance. However, the issue of how adoption of market orientation contributes to the ever-increasing need of developing the stock market is under researched. This is because previous market orientation researches have been firm and industry specific (Kohli \& Jaworski, 1990; Narner \& Slater, 1990; Hafer \& Gresham, 2008; Amirkhani \& Sanavi Fard, 2009), with almost little or no attention to the stock market situation. Considering the financial sector reform programmes implemented by developing countries, particularly African countries in the late 1980s and early 1990s, developing economies are doing everything to develop and grow the stock markets. The stock market is considered to contribute significantly to national economic growth and development, in both developed and emerging economies (Hondroyiannis, Lolos \& Papapetrou, 2004; Ezeoha, Ogamba \& Oyiuke, 2009). The stock market is also expected to encourage public participation in listing on the market in particular and promote economic growth in general (Caporale, Howells \& Soliman, 2004). Developing the stock market in developing countries to necessitate economic growth and national development requires that organisations are not only able to raise capital. Importantly they should also be able to have markets for their products and services. In connection with this researchers have argued that it is the economic activities in a country that constitute the key drivers of stock market development (Yartey, 2008). This suggests that the attraction and sustenance of firms to the stock market is better achieved if listed firms can grow their business through increased volume and value of sales.

The expectant increase requires firms to adopt market orientation behaviour. Therefore, to acknowledge the role of market orientation in the development and growth of the stock market, the level of market orientation and its consequence effects on listed firms' performance must be established. The development of the stock market, among other factors shall include the number of firms that list on the stock market. Yet, many firms are more inclined to growing their market share and profitability than just mobilising capital and savings, which have always been emphasised as benefits for listing. Such organisational performance has been linked to the market orientation of a firm (Alhakimi \& Baharun, 2009; Malik \&Naeem, 2009; Qu \& Ennew, 2009).

The related literatures suggest that knowledge of the market orientation of Listed Firms is critical to the development of stock markets, especially in developing countries. However, studies on how the consequent 
performance of market orientation could contribute to the development of the stock market are under researched. This creates a gap in the extant literature, which need to be addressed. This study thus addresses this important gap by investigating the level of market orientation and its effects on organisational performance of Listed Companies. The study also tries to establish the potential role of listed firms' level of market orientation in the development of the stock market

\section{Research Problem:-}

The contribution of the stock market as an engine of growth has been supported by the literature (Mun, Siong \& Thing, 2008; Ezeoha, Ogamba \& Oyiuke, 2009; Salisu \& Ajide, 2010). Thus, a vibrant stock market development for emerging economies cannot be overemphasised. However, most developing countries have not been able to develop such a vibrant stock market needed for national growth and development. Though the International Monetary Fund's (IMF) survey of 2007 notes that there has been a considerable development in the stock markets in developing countries, particularly, Africa since the early 1990s, the sector is still struggling to make the desired impact. Statistics of stock market development show that African markets are relatively small with few Listed Companies and low market capitalization (Yartey \& Adjasi, 2007).

The inability of sector players to expand and attract more companies to the stock market could be attributed to the overemphasis on capital and savings mobilization as key benefits of listing on the market (Yartey, 2008; Ezeoha, Ogamba \& Oyiuke, 2009; Salisu \& Ajide, 2010). A critical area of concern is how this capital and savings mobilised translate to organisational performance in the form of profit, market share and customer orientation (Malik \& Naeem, 2009; Qu \& Ennew, 2009; Bytyqi, Zeqiri \& Hasani, 2010). This means the market orientation and its associated impact on performance of Listed Companies might be an impressive barometer for judging the effectiveness and efficiency of the stock market and thereby using the results to attract more qualified organisations into the market. This should foster the development of the stock market and thus contribute to national growth and development. The failure of previous studies to investigate the market orientation and performance of Listed Companies, (rather than putting more emphasis on firm and industry specific context studies) suggests existing information on stock market performance with regards to market orientation and its related organisational performance is scanty. This means less knowledge and appreciation of the relative level of market orientation and organisational performance of companies in the stock market and its role to stack market development. Thus, the role that market orientation adoption could play in stock market development must not be overlooked. Therefore, it is justified that this study is undertaken to address the lack thereof. The research investigates the level of market orientation of Listed Companies so as to lay bare the role of market orientation in the development of the stock market, alongside other considerations as capital and savings mobilization.

\section{Research Questions:-}

1. What is the level of market orientation of Listed Companies?

2. What link, if any exist between market orientation and organisational performance of Listed Companies?

3. What is the degree of variation between market orientation and organisational performance, by type of firm and number of years an organisation has listed on the Stock Market?

4. What is the perceived relationship between market orientation adoption and development of the stock market?

\section{Literature Review:- Market Orientation:-}

Market orientation is a marketing term that could be traced back to the work of Drucker (1954) who postulated that the customer must be the focus of organisation's operations. This idea was subsequently support by Levitt (1960) that the customer is the reason for the organisation's existence. These authours were suggesting that market-oriented behaviour was necessary at that time as it is today. Following from the earlier works, the subject matter of market orientation has received a great deal of attention from marketing scholars who have developed, tested and refined market orientation scales for measuring the degree of market orientation that organisations exhibit (Kohli and Jaworski, 1990; Narver, Slater \& MacLachlan, 2004; Merlo \& Auh, 2009).

The literature identifies market orientation as a central theme of modern marketing science, which basically originates from the marketing concept or a business orientation of a firm. Market orientation, can be described as an ideal or a policy statement, which defines the understanding and meeting of customers' needs as the key to competitive advantage. Therefore, the level of market orientation of an organisation might be dependent on the extent of implementation of the marketing concept (Pitta \& Richardson, 2007). Consistent with previous studies, this 
study, views market-oriented companies as those whose actions are consistent with the two dominant conceptualizations of market orientation developed by Kohli \& Jaworski (1990) and Narver \& Slater (1990). Wrenn, Souder \& Berkowitz (2000) and recently Voola \& O'Cass (2010) drew a distinction between market orientation and marketing concept. They identified the marketing concept as a way of thinking about the organisation, its products, and its customers and; market orientation as doing those things which are necessary to put the philosophy in practice.

Furthermore, Mavondo, Chimhanzi \& Stewart (2005) identify market orientation as a business behaviour that fosters the organisation's continuous learning about its customers and competitors. Similarly, the literature suggests that a market orientation is concerned with pursuance of intelligence pertaining to customers, competitors (Hafer \& Gresham, 2008; Kotler \& Armstrong, 2010) and intelligence acquisition, intelligence dissemination and responding to intelligence (Qu \& Ennew, 2009). Mavondo, Chimhanzi \& Stewart (2005) also asserted in connection with market orientation, "a market orientation is an important antecedent to product innovation, process innovation and administrative innovation" (p. 1256). Some literatures also use the variable 'customer orientation' interchangeably with market orientation, while some differentiate between the two (Hammond, Webster \& Harmon, 2006). This suggests that being market oriented requires that a firm is customer focused, while providing customer needs and preferences.

The recognition, adoption and implementation of the marketing concept, which leads to attainment of market orientation, should shape management of the companies of the Stock Market in designing and implementing business practices and processes as well as allocating resources. This should aim at making the companies become more oriented towards the market which would result into improved organisational effectiveness and sustained competitive advantage (Narver, Slater \& MacLachlan, 2004; Voola \& O'Cass, 2010). Management of these companies needs to note that market orientation is made possible through adoption of the marketing concept. However, adoption of the marketing concept is not enough; it must be implemented because this is a necessary condition for market orientation. It should be appropriate for organisations to adopt business practices that ensure that key antecedents factors are put in place to generate the desired market orientation behaviour which fosters organisational performance.

This study conceptualises market orientation as a combination of different perspectives (Zebal, 2003; Alhakimi \& Baharun, 2009; Bytyqi, 2010). In this connection, market orientation may be defined as:

'a business culture that generates information about the whole market (customers, employees and competitors), disseminate such information about customers to all levels of the firm, in such a responsive manner that ensures provision of customer value in order to satisfy customers, to the extent that they make it possible for the organisation to achieve its ultimate objective - profitability, in an optimum way, relative to its competitors'.

This definition is in harmony with that of Deng \& Dart (1994), in whose attempt to move towards a resolution of the confusion within the market orientation literature, defined market orientation as "the generation of appropriate marketing intelligence pertaining to current and future customer needs, and the relative abilities of competitive entities to satisfy these needs; the integration and dissemination of such intelligence across departments; and the coordinated design and execution of the organisation's strategic response to market opportunities”(p.726).

\section{Market orientation and firm performance:-}

Many of the market orientation studies have supported a positive correlation between market orientation and organisational performance (Gonzalez-Benito, Gonzalez-Benito \& Munoz-Gallego, 2009). Nevertheless, a few other studies reported an insignificant relationship between a market orientation and organisational performance (Merlo and Auh, 2009). More specifically, Kirca, Hultink \& Robben (2005) report that a market orientation positively affects the overall organisational performance: profits, sales growth, market share, perceived quality, customer loyalty and customer satisfaction. Narver, Slater \& MacLachlan (2004) aver that a company should constantly increase its proactive market orientation in order to create and maintain a sustainable competitive advantage. Recently, other studies have supported this by suggesting that a proactive market orientation has a stronger influence on organisational performance than a responsive market orientation (Voola \& O'Cass, 2010). This implies that firms that take initiative to improve their market orientation behaviour deliver superior performance than those who just react to market orientation needs. Thus, the higher the level of market orientation of listed firms, the greater should be their performance, and the better this should provide a source to develop the stock market. 
The prevalent empirical literature actually confirms a positive impact of market orientation on performance (Kirca, Jayachandran \& Bearden, 2005; Gonzalez-Benito, Gonzalez-Benito \& Munoz-Gallego, 2009). This organisational performance could be grouped into non-economic performance, measured by customer satisfaction, customer loyalty, customer retention, providing value for customers, spreading a sense of pride among employees, organisational commitment, employee-team spirit and customer orientation (Homburg \& Pflesser, 2000). It also includes economic performance, measured by profits, sales growth and return on investment (Jimenez-Jimenez et al., 2008; Merlo and Auh, 2009). As per the literature, this study measures the performance of Listed Companies using economic indicators like profitability, return on investment (ROI) and sales growth (Jimenez-Jimenez, Valle \& Hernandez-Espallardo, 2008; Merlo \& Auh, 2009). Similarly, non-economic performance is measured by employees' commitment, espirit de corps, customer satisfaction and customer retention (Homburg \& Pflesser, 2000). Market orientation is significantly important in enabling firms to understand the market place and develop appropriate product and service strategies to meet customer needs and requirements (Liu, Li \& Zhao, 2006). A market orientation assures a customer focused strategy for market knowledge-base generation, which brings about coordinated, inter-functional marketing efforts to achieve long-term success. Market orientation is significantly important in enabling firms to understand the market place and develop appropriate product and service strategies to meet customer needs and requirements (Liu, Li \& Zhao, 2006).

\section{Research Design:-}

Given the lack of research on the market orientation in the Stock Market, the study used qualitative approach in lieu of the more conventional survey method, in an attempt to 'generate new, exploratory theories' in relation to the development of market orientation and the stock market. The study conducted a total of eleven in-depth interviews questions with top managers of Listed Companies in Ghana. The first five in-depth interview questions were to determine the relationship between market orientation and a firm's performance. The last six questions, on the other hand, were to assess companies' perception regarding how adoption of market orientation could contribute to development of the stock market in Ghana. The in-depth interview questionnaire for this study is designed for interviews with case study companies. Drafts of in-depth questions were developed and reviewed in consultation with two academic supervisors before the final interview questionnaire was adopted for the case companies. The questions involved major market orientation questions that served as bases for answering the four research questions.

The study's population comprised 36 listed companies of the Ghana Stock Market. Since the research is a case study, 10 companies were selected for the study. Given attention to theory development rather than theory testing, the research followed Kohli and Jaworski (1990) and used a purposive sampling plan in the selection of the interviewees. For instance, a special effort was made to include in the sample, informants of every classified industry to reflect the diversity in company structures characterising the stock market. As a result, the sample included managers from companies of a wide range of industry types and stock market experience. The informants were males and females CEOs, human resources managers and marketing managers with more than 10 years' experience of working in current positions. A total of 30 participants were selected from 10 participating companies to take part in the in-depth interview. Although a small, non-random sample (i.e. 10 companies from the total of 36 companies) means that the findings from the informants may be limited in terms of generalisability, such a limitation is not deemed a serious problem at this stage as the interviews are exploratory in nature. The interviews lasted from thirty minutes to one hour and were audio-taped unless the interviewees requested otherwise. All interviews were conducted at convenient time and place of interviewees.

Content analysis technique was adopted to analyse the data. The analysis of the transcribed data was done in a logical, systematic and prescribed manner. Thus, all responses which were similar in nature and understanding were identified from the data matrix. These were coded and categorized, using the most frequent mentioned responses. After the coding and categorization, frequencies for each category were identified to serve as the basis for the presentation of the findings. 'Exact Language' of the respondents were used. 'Exact Language' refers to presenting the responses exactly as said by the respondent without paraphrasing or translating the meaning. The study preferred the narrative presentation of results to other methods because the former is popular and has been used in previous qualitative market orientation researches (Blankson \& Omar, 2002; Zebal, 2003). 


\section{Results:- \\ Level of Market Orientation of Listed Firms:-}

The qualitative results suggest that the level of market orientation of a listed firm is relatively high, and attributed this to the contributions made by key management, organisational and external antecedents. The findings indicate that lack of quality managers has significant effects on a company's ability to generate and respond to market intelligence (Harris, Andrews \& Kacmar, 2007). Interviewees stressed the importance of management characteristics to adoption of market orientation, as the following quotes demonstrate:

"The quality of our managers poses to be one of the biggest challenges we have to deal with. At the moment, our managers' clear understanding of the meanings of modern management and marketing is a critical factor. As the market change from a seller' market which we enjoyed for the past years to a buyer' market, the incompetence of our managers have great consequences for our business." (Human Resources Manager of a Pharmaceutical Company)

The company is very committed to management training. Every year the company sponsor some senior managers to GIMPA to up-grade themselves on modern business practices, especially in customer care. Apart from that, some of the sales people are also sponsored to up-grade their sales and marketing skills (Marketing Manager of a Cocoa Processing Company).

From these statements, it is proposed that, the greater endowment of managerial talents, leads to the relatively high level of market orientation. Thus management antecedents contribute to relatively significant level of market orientation.

Again, the results from the data suggest that the lack of quality organisational settings have serious implication on a company's ability to be market oriented (Lopez-Cabrales et al., 2006; Song et al., 2007). Respondents emphasised the significant contribution of organisational antecedents to the current attainment of market orientation, as the following quotes demonstrate:

"Our company does not joke with any organisational issues, whether they have direct or indirect consequences on the success of our business.” (Marketing Manager of a Beauty/Health Products Company)

"We have qualified pharmacists, engineers, accountants and marketers. We also have well equipped quality control department that ensures the company meets technical standards. Therefore I can say our company is technically capable to live up to the customer services requirements." (A General Managers of a Pharmaceutical Company)

Most of the values are enshrined in the company's policies, which every staff must comply. Every new employee is taken through orientation. Among the things considered in the orientation is the company's shared values and beliefs. As much as possible, all staffs comply with the code of ethics of the company (Manager of a Manufacturing Company).

From the above quotes it is proposed that, the level of market orientation of listed firms is high when there is efficient management of organisational internal environment.

Furthermore, the results from the interviewees suggest that a firm's inability to effectively manage its immediate external environment can lead to negative consequences on the company's requirement to be market oriented (McNaughton \& Schlosser, 2004). Respondents stressed the significant role the external environment plays in determining the current level of market orientation of a firm. This is suggested by the following quotes:

"Strategic management requires that due attention is paid to external factors that potentially affect our business. Ignorance about this fact for a moment will surely put all your good strategy into nothing" (CEO of a Publishing Company)

"Our reason for trying to provide customer needs according to changing preferences is to improve on our customer services capability and thereby create and maintain profitable customers. Interestingly, our customers' preferences don't change much so our customer needs seems to be quite stable. When the preferences do change we react appropriately" (Human Resources Director of a Manufacturing firm). 
I think our industry experiences one of the most intense competitions. Every now and then a new bank is opened in the country. Yes from the look of things competition really compels us to adopt to market orientation but for the cost" (Human Resources Manager of a Commercial Bank).

From the above quotes it is proposed that, the swiftness with which a firm attends to its external environment, the greater the level of market orientation of the firm.

Relationship between Market Orientation and Organisational Performance:-

The results from the respondents interviewed suggest that the level of market orientation affects organisation's performance more than any other determinants of business (Mukherjee \& Malhotra 2006; Hafer \& Gresham, 2008). Interviewees stressed the positive relationship between market orientation and organisational performance in these ways, as the following quotes demonstrate:

"I know business success depends on many interrelated factors, but none of these can be compare with the level of market orientation of the firm" (Managing Director of a Cocoa Processing Firm).

"Every customer is on our database so we always have information about our customers. We have contact numbers of our customers and we do call them as often as practicable to know their problems as well as how they so much appreciate our products and services. We also conduct formal research from time to time to investigate our customers' likes and dislikes. This is our secrete of satisfied and loyal customers" (General Manager of a Computer/Media Solution Company)

We have inter-departmental meetings every week. Then every quarter, we have quarterly meetings for all staff. At every meeting, the attention is always on the customer. When we meet, we first listen to employees experiences about the customers from the field. Then we also find out how they dealt with each situation for the benefit of the customer. Then useful suggestions are made for future occurrences. This approach have contributed greatly to the staffs commitment to work, and has also resulted in increased profit" (Commercial Director of a Manufacturing company).

From the above quotes it is suggested that, the higher the level of market orientation, the greater the organisational performance of a Listed Firm.

\section{Variability between Market Orientation and Firm Performance by Industry Type and Number of Years Listed:-}

Regarding the extent to which market orientation and firm performance vary by industry type and years of listing experience, the results from the qualitative data suggest that once a firm lists on the stock market it has only a short while to adapt to market orientation due to the customer-centric culture of the market. The findings also indicate that whichever industry a firm belongs, or any reasonable number of years a firm has listed, is just enough to make a firm market orientated and consequently enhance its organisational performance. Respondents emphasised the direct positive relationship between listing on the stock market and a firm's market orientation and organisational performance, as the following quotes demonstrate:

"It did not take our company anything more than two years to attain to market orientation after listing on the stock market, and I think that can be said of all Listed Companies as far as I am aware" (General Manager of a Development Bank)

"I least know that we could also behave like a marketing company that have customers whose needs and preferences must be met until after our company has listed on the stock market" (Customer Services Engineer of a Mining company).

From the above quotes it is proposed that, market orientation of a Listed Company does not vary by industry or years of experience in the market. Thus, once a company lists on the stock market it adopts the market orientation culture within a shortest possible period which enhances the firm's performance. 
Again, the results from the respondents interviewed suggest that they better appreciate market orientation as an important business phenomenon. Informant indicated that market orientation is a key characteristic of the stock market, and that once a company joins the market it is bound to adopt a higher level of market orientation. Interviewees stressed the important relationship between listing and a firm's market orientation and organisational performance, as the following quotes demonstrate:

"Our company didn't have direct department for customer service until we listed on the stock market. The reason was that even though we served customers we did not find it necessary to have a senior officer just in charge of customer care. Today we have a whole commercial director whose primary function is to develop marketing programmes to provide value and profitable customers” (Human Resources Manager of an Oil company)

"Honestly, our current focus on our customer needs and preferences is credited to management ability to list the company on the stock market. We are a better customer-centred organisation today than we were yesterday" (General Manager of a Manufacturing Company)

From the above quotes it is proposed that listing on the stock market is a catalyst for market orientation of a firm. Thus, the more companies list on the stock market the greater the all-embracing culture of market orientation of the economy.

Also, the findings suggest that many companies appreciate the positive link between market orientation and organisational performance better than before. Respondents stressed the connection between knowledge of market orientation and organisational performance relationship when you are a Listed Company than when you are not listed, as the following quotes demonstrate:

"I must confess that market orientation is not a new subject to our company, but I can stress that the way we know of market orientation and how it fosters organisational performance is better than some years ago" (Marketing Manager of a Health/Beauty company).

"Am not in a position to gauge the level of appreciation of companies outside the stock market regarding the positive relationship between market orientation and organisational performance. But at least I can say from experience with conviction that Listed Companies have high appreciation of the positive relationship between market orientation and organisational performance" (Customer Services Manager of an Insurance company).

Role of Market Orientation Adoption and Development of the Stock Market:-

In connection with the positive relationship between a firm's market orientation and the development of the stock market, the qualitative findings indicate that interviewees strongly believe that adoption of market orientation behaviour as a culture needs much emphasis as a means of attracting more companies to the stock market, as it is done with capital and savings mobilization. Similarly, respondent ranked market orientation as high as capital and savings mobilization in terms of benefits of the stock market that market players can use to attract more companies to the market. The following quotes demonstrate the views of interviewees:

"If you ask me I will tell you that companies would like to list to benefit from capital and savings mobilisation. Yet, I think many more companies might be encouraged if they come to appreciate that beyond the traditional benefits, listing can enhance their market orientation and foster their organisational performance" (CEO of a Cocoa Processing company)

"True, it is important to mobilise capital and savings as a company, but no commercial benefits would be derived if the company after all is unable to sell its product competitively because it did not provide customer needs and preferences. You would agree with me that market orientation should even be stressed more than capital and saving mobilisation" (Customer Relations Manager of a Commercial Bank).

From the above quotes it is proposed that, market orientation of listed firms should have a positive direct effect on the development of the stock market. Thus, the higher the level of market orientation of listed firms, the greater it should be a motivator for the development of the stock market in developing economies. 
Overall assessment of the responses from the interviewees suggests that: First, market orientation is synonymous with listing on the stock market. This suggests that listing improves the market orientation of a firm. Second, awareness of market orientation performance relationship of Listed Companies is relatively high. Thus, the more firms are encouraged to list on the stock market, the more likely it is to improve the market orientation culture of the economy. Lastly, market orientation is perceived to be a critical condition that has the potential of encouraging listings on the stock market, alongside capital and savings mobilisation. This means the more emphasis is placed on market orientation as benefit of listing, the greater the number of companies that might consider going to the stock market, and the better the stock market development will see 'light of day'.

Therefore, on the basis of the qualitative analysis, it is proposed that market orientation can contribute to development of the stock market in developing economies.

\section{Discussion:- \\ Research Question One:-}

The first research question relating to possible higher level of market orientation, showed a relatively high level of market orientation of Listed Companies. This high level is a result of effective contribution of management, organisational and external factors. This indicates that overall market orientation of a firm is high with the existence of key antecedent factors that determine market orientation. Categorically, however, the more efficient a firm is in integrating its managerial, organisational and external characteristics, the higher the market orientation. The positive and significant contribution of management, organizational and external antecedents to the high level of market orientation of listed companies is consistent with the findings of Hammond, Webster \& Harmon (2006); Malik \& Naeem (2009); and Erdil, Kitapci \& Timurlenk 2010).

\section{Research Question Two:-}

The second research question relating to possible higher significance relationship between market orientation and firm performance, showed a direct positive relationship between market orientation and both economic and noneconomic performance. This direct positive relationship between market orientation and firm performance is confirmed by the interviewees who stated that organisational performance is the end product of market orientation. Thus, in order to attain to a high level of economic and non-economic performance, a firm must do everything possible to enhance its market orientation behaviour. The positive link between market orientation and organisational performance is consistent with the previous works by Blankson \& Omar (2002); and Ismail (2009).

\section{Research Question Three:-}

In the third research question relating to possible variation of market orientation and organisational performance by type of industry and number of years experience in the stock market, the qualitative findings showed that market orientation does not require that a firm list for relatively long period or has to belong to a specific type of industry. The interviewees by their quotes suggested that market orientation of Listed Companies is not varied by industry type or years of listing experience. This means, the more firms list on the stock market the higher will be their market orientation behaviour and consequently, their organisational performance. Therefore, in order to ensure a wide range of market orientation culture, developing economies must 'widen the net of the stock market to catch more companies' into the' list net'. The results of the question which suggests that market orientation of a Listed Company does not vary with type of industry or number of years' experience in the market is consistent with Pitta \& Richardson (2007), who confirmed that market orientation of both Chinese and US firms do not vary by industry type or size.

\section{Research Question Four:-}

The fourth research question relate to perceived link between existence of market orientation and development of the stock market in developing economies. The qualitative findings show that it is perceived by informant of participating companies that existence of market orientation could be a potential source to develop the stock market. This indicates that existence of market orientation is an important determining factor for attracting more companies to the market. Thus, in order to develop and grow the struggling stock market, managers of developing economies could stress on attainment of market orientation and its associated economic and non-economic performance as one of the benefits gained by listing, alongside the traditional benefits of capital and savings mobilisation. This should encourage more qualified companies to want to list on the stock market and thereby contribute to the development and growth of the stock market. 


\section{Contributions of the Current Study:-}

An emerging body of literature on market orientation seeks to identify key antecedents required for market orientation to occur, and subsequently foster organisational performance. The study contributes to that body of knowledge by identifying a set of constructs that should be present to determine the level of market orientation. Further, the results show that existing of market orientation leads to organisational performance of a firm and consequently development of the stock market. For this reason, it is important government support Listed Firms to become market oriented. In summary, the present study makes the following contribution:

1. This study shows that organizational and external antecedents make high contributions to the relatively high level of market orientation than management antecedents, which information is not found in previous studies.

2. Investigations into market orientation by earlier writers have been conducted mainly in firm and industry specific contexts in both developed and developing economies. This has shown inconsistent results in developing countries. Nonetheless, this research was conducted in a stock market context as a means of supporting the development of stock market in developing countries.

3. This study, unlike previous ones also suggests that what a firm needs to be market orientated is not the industry type or how long it has listed on the stock market. Once a firm list on the stock market for a relatively short period, irrespective of industry type it is able to adopt the market orientation culture.

4. The study again shows that market orientation could be used as a motivating factor to encourage more firms into the stock market, alongside other traditional motivating factors such as capital and savings mobilisation. This findings is useful for promoting the development of the stock market in developing economies

\section{Policy Implications:-}

From the perspective of policy makers, a number of important conclusions may be drawn, although these conclusions must necessarily be restricted to the context of a developing economy. First, it is noted that in the context of a developing economy, government regulations can have both negative and positive effects on market orientation as a motivator of developing the stock market. To the extent that promoting market orientation is seen as desirable in order to enhance the development and growth of the stock market in developing economies, the findings suggest that policy makers need to pay particular attention to the configuration of existing regulations as they affect business. Regulations which constrain focus on market orientation and over emphasise capital and savings mobilisation would have a detrimental effect on the development of the stock market in developing economies. At the same time, there may be a case for tightening up the existing regulations or even developing new regulations to enhance levels of consumer protection, encourage increases in product quality and generally provide greater incentives for a move towards market orientation.

In addition, there may also be a role for governments in developing economies in helping firms to become more market-oriented by fashioning out policies that provide solutions to the shortage of competent managerial and marketing talents. As a major provider and sponsor of education and training, there is considerable potential for government policy to attempt to improve the availability of well trained and market oriented managers to the business community.

Finally, governments of developing economies have a duty to create an enabling external environment that promotes business. As a leader in setting the agenda for the whole business environment, government will need policies that control unhealthy competition, promote technology transfer and strengthening the fibre of the economy. These will provide incentives for a market orientated business culture and consequently help develop stock markets in developing economies.

\section{Limitations and Further Research:-}

For this investigation into the development of market orientation in developing countries, the study used only Listed Companies in Ghana. As such, it begs a question of whether the research findings are generalisable to other markets in developing economies, especially the markets in Africa. Further research in such diverse contexts might be necessary to improve the understanding of the challenges relating to developing market orientation in developing countries. Again, it should also be noted that though the study has focused on the environmental determinants of market orientation, clearly even in the Stock Market managerial actions can lead to differences in market orientation for firms facing similar environmental conditions. As an exploratory study, the main purpose in this study is to highlight the most challenging issues that face firms in the stock market in their development of market orientation. However, the study did not seek to provide an exhaustive list of barriers to market orientation. It is recognised that a 
variety of other factors such as interdepartmental connectedness, organisational ownership structure and government regulations may also present challenges to the development of market orientation in Ghana. These factors might be considered in future research.

Arguably, the study also used only qualitative data to measure the level of market orientation. Future studies may consider using quantitative data in addition to the qualitative data. Finally, from a methodological standpoint, data in this study were obtained from top managers. It would be useful to obtain a broader sample of managers and perhaps even non-managers in future studies so that any potential bias in the data resulting from the level of the informants would be minimised.

\section{Acknowledgement:-}

I acknowledge that this paper is an original work of the author, who has marketing background. The author of the current study owns his gratitude to all previous writers whose works have contributed to this article.

\section{References:-}

1. Alhakimi, W. \& Baharun, R. (2009) A Synthesis Model of Market Orientation Constructs Toward Building Customer Value: A Theoretical Perspective, African Journal of Marketing Management 1(2) 43 - 49

2. Alhakimi, W., Baharun, R. (2010) "An Integrative Model of Market Orientation Constructs in Consumer Goods Industry: An Empirical Evidence", International Management Review, 6(2) 40-54.

3. Amirkhani, A \& Sanavi Fard, R (2009) The Effect of Market Orientation on Business Performance of the Companies Designing and Manufacturing Clean Rooms, American Journal of Applied Sciences 6 (7) 13731379.

4. Blankson, C. \& Omar, O. (2002), Marketing Practices of African and Caribbean Small Business in London; UK, Corporate Communications: An International Journal, 5 (2) 107-112

5. Bytyqi, F, Zeqiri, N. \&Hasani, V. (2010) Internal Perspectives of Market Orientation: Case of Central Public Organisations in Kosovo, Research Journal of International Studies (17)

6. Caporale, G. M., Howells, P. G. A., \& Soliman, A. M. (2004). Stock market development and economic growth: The causal linkage. Journal of Economic Development, 29(1), 33-50.

7. Chen, S.C.\& Quester, P. (2009).A value-based perspective of market orientation and customer service. Journal of Retailing and Consumer Services, 6, 197-206.

8. Deng, S. \& Dart, J. (1994).Measuring market orientation: A multi-factor, multi-item approach. Journal of Marketing Management.10, 725-742.

9. Drucker, P. F., (1954). The Practice of Management, Harper and Row, New York.

10. Erdil, O. Kitapci, H. \& Timurlenk, B. (2010) Effects of Core Employees on Organisational Capabilities and Firm Performance, Journal of Global Strategic Management, 7, 30 - 38.

11. Ezeoha, A., Ogamba, E. and Oyiuke, O. N. (2009).Stock market development and private investment growth in Nigeria. Journal of Sustainable Development in Africa, 11(2) 20-35.

12. Felix, R. \& Hinck, W. (2005). Executive insights: Market orientation of Mexican companies, Journal of International Marketing, 13(1) 111-27.

13. Gonzalez-Benito, O., Gonzalez-Benito, J. \& Munoz-Gallego, P.A. (2009).Role of entrepreneurship and market orientation in firm's success. European Journal of Marketing, 43 (3/4), 500-522

14. Grönroos, C. (2006). On defining marketing: finding a new roadmap for marketing. Management theory, 6(4) 395-417.

15. Hafer, J. \& Gresham, G.G (2008) Organisational Climate Antecedents to the Market Orientation of CrossFunctional New Product Development Teams. Journal of Behavioural and Applied Management, 9(2) 184

16. Hammond, K L., Webster, R. L. \& Harmon, H. A. (2006) Market orientation, top management emphasis, and performance within university schools of business: implications for universities. Journal of Marketing Theory and Practice, Winter, 14(1) 69-85.

17. Harris, K.J. Andrews, M.C. \& Kacmar, K.M., (2007).The moderating effects of justice on the relationship between organisational politics and workplace attitudes. Journal of Business and Psychology, 22, 135-144.

18. Homburg, C.H \& Pflesser, C.H. (2000) A multiple-layer model of market-oriented organisational culture: Measurement issues and performance outcomes. Journal of Marketing Research, 37, 449 - 462.

19. Hondroyiannis, G., Lolos, S., \& Papapetrou, E. (2004). Financial markets and economic growth in Greece. Journal of International Financial Markets, Institutions and Money, 15(2), 173-188.

20. Ismail, S T. (2009), The effect of Relationship Marketing on Organisational Outcomes "An Apply Study in Jordanian insurance companies" European Journal of Social Sciences, 12(2) 176-184. 
21. Jaworski, B.J., and Kohli, A.K. (1993). Market Orientation: Antecedents and Consequences. Journal of Marketing, 57, 53-70.

22. Jimenez-Jimenez, D., Valle, R. S. \& Hernandez-Espallardo, M. (2008).Fostering innovation: the role of market orientation and organizational learning. European Journal of Innovation Management, 11 (3) 389 - 412.

23. Kirca, A. H., Jayachandran, S. \& Bearden, W. O. (2005). Market orientation: A meta-analytic review and assessment of its antecedents and impact on performance. Journal of Marketing, 69(2) 24-36.

24. Kohli, A.K, \&Jaworski, B.J, (1990). Market orientation: The construct, research propositions and managerial implications. Journal of Marketing, 54, 1-18.

25. Kotler, P. \& Armstrong, G. (2010) Principles of Marketing, New Jersey, Pearson Education

26. Levitt, T (1960), "Marketing Myopia", Harvard Business Review, 38(4).

27. Liu, Y., Li, Y. \& Zhao, Y (2006). The role of market and entrepreneurial orientation and internal control in the new product development activities of Chinese firms. Industrial Marketing Management 35, 336-347.

28. Malik, M. \& Naeem, E. B. (2009) Identification of Drivers and Obstacles of Market Orientation among Diversified Industries of Pakistan, A Research Journal of South Asian Studies 24(2) 322-33.

29. Mavondo, F. T., Chimhanzi, J. \& Stewart, J. (2005).Learning orientation and market orientation: Relationship with innovation, human resource practices and performance. European Journal of Marketing, 39, 1235-1266

30. Mokhtar, S.S. M., Yusoff, R.Z. \& Arshad, R. (2009) Market Orientation Critical Success Factors of Malaysian Manufacturers and Its Impact on Financial Performance, International Journal of Marketing Studies 1(1) 77 84

31. Mukherjee, A., \& Malhotra, N. (2006), "Does Role Clarity Explain Employee-Perceived Service Quality?" International Journal of Service Industry Management, 17 (5), 444 - 473.

32. Mun, H. W., Siong, E. C., \& Thing, T. C. (2008). Stock Market and Economic Growth in Malaysia: Causality Test. Asian Social Science, 4(4).

33. Narver, J. \& Slater, S. (1990). The effect of a market orientation on business profitability. Journal of Marketing, 54(4) 20-36.

34. Narver, J.C., Slater, S.F. \& MacLachlan, D.L., (2004).Responsive and Proactive Market Orientation and NewProduct Success. The journal of product innovation management 21 (5) 334-374.

35. Pitta D.A \& Richardson L. (2007). A Comparison of the Market Orientation of Chinese and US Firms. International Business \& Economics Research Journal. 6(12)

36. Qu, R. \&Ennew, C.T. (2009) Developing a Market Orientation in a Transitional Economy: The Role of Government Regulation and Ownership Structure. Journal of Public Policy and Marketing, 24(1).

37. Salisu A. A. \& Ajide K. B. (2010).The Stock Market and Economic Growth in Nigeria: An Empirical Investigation: Journal of Economic Theory, 14, 65-70

38. Savitt, R. (2001), "Understanding Marketing Development in the Czech Republic", European Journal of Marketing, 35(11) 1386-1397.

39. Slater, S.F. and Narver, J.C. (1994), 'Does competitive environment moderate the market orientation performance relationship'? Journal of Marketing, 58, 46-55.

40. Tomaskova, E. (2009) Internal Barriers of Market Orientation Application, Economics and Management: 14, 1 -6 .

41. Voola, R. \& O'Cass, A. (2010) Implementing competitive strategies: the role of responsive and proactive market orientations. European Journal of Marketing, 44 (1/2), 245-266.

42. Wren, B.M., Souder, W. E. \& Berkowitz, D (2000). Market Orientation and New Product Development in Global Industrial Firms. Industrial Marketing Management 29, 601-611.

43. Yartey, A. C. (2008). The determinants of stock market development in emerging economies: Is South Africa different? IMF Working Paper No. WP/08/32. Washington D.C.: International Monetary Fund.

44. Yartey, A. C. \& Adjasi, K. C. (2007). Stock market development in Sub-Saharan Africa: critical issues and challenges. IMF Working Paper No. WP/07/ 209. Washington D.C.: International Monetary Fund.

45. Zebal, M. A. (2003) A Synthesis Model of Market Orientation for Developing Country - A Case of Bangladesh, PHD Thesis, Victoria University, Melbourne, Australia

\section{Appendix: -}

Qualitative Research Questions:-

Contribution of Antecedents Factors to the Level of Market Orientation

What is the importance of management factors to the development of high standard of market orientation of your firm? 
This question requires respondents to indicate the role management antecedents play in determining the level of market orientation of a Listed Company.

How would you classify the contributions that organisational antecedents make toward a high standard of market orientation of your company?

This question aimed at ascertaining the views of respondents regarding the degree to which organisational antecedent factors influence the level of market orientation of Listed Companies.

Do you share the view that external antecedent factors have great influence on the level of market orientation of your firm?

This question inquires from respondents, the significant contribution of external environmental factors on a Listed Firm's level of market orientation

Relationship between Market Orientation and Organisations' Organisational performance Would you say that your company's organisational performance have anything to do with the level of market orientation?

The question was intended to ascertain whether the performance of a Listed Company is related to the firm's level of market orientation.

Variability of Market orientation and Organisational performance relationship by Demographic Variables In the Stock Market, can you say that the level of market orientation of some a firm is higher than others because of differences in industry or number of years listed?

The basis for asking this question was to whether listing on the stock market is just necessary and sufficient precursor for a firm's market orientation

Relationship between Adoption of Market Orientation and Development of the Stock Market How would you compare your company's level of market orientation relative to when you were outside the stock market?

Would you say market orientation adoption is synonymous with listing on the stock market?

These questions were to establish the relationship between market orientation and organisational performance. They were also to determine respondents' view of how the stock market contributes to a firm's market orientation.

Did you know the market orientation performance relationship before your company listed on the stock market?

Would you say most companies that have not listed do not still have appreciable knowledge of market orientation and organisational performance relationship?

These questions were to determine knowledge of companies that have not yet listed on any relationship between listing and being market oriented.

Capital and savings mobilisation are the two primary factors that are usually emphasised as reasons for listing on the stock market. As per experience, would you say adoption of market orientation needs equal emphasis?

How would you rank the three primary motivating factors (capital mobilisation, savings mobilisation and adoption of market orientation in order of their competitive advantage?

These questions were to first establish the role of market orientation to the development of the stock market; and second to determine the competitiveness of market orientation to the development of the stock market 